\title{
Age-Related Changes in Adenylate and Guanylate Cyclases from Rhesus Muscle: Sensitivity to Positive Modulators
}

\author{
C. H. BEATTY, ${ }^{(44)}$ P. T. HERRINGTON, R. M. BOCEK, AND M. K. YOUNG \\ Division of Perinatal Physiology, Oregon Regional Primate Research Center, Beaverton, Oregon and Department of \\ Biochemistry, University of Oregon Health Sciences Center, Portland, Oregon, USA
}

\begin{abstract}
Summary
The basal adenylate cyclase activities, per $\mathrm{g}$ wet wt, of homogenates of adult skeletal muscle $(4 \pm 0.4 \mathrm{~S}$.E. nmoles $/ 10 \mathrm{~min} \cdot \mathrm{g}$ wet $\left.\mathrm{wt}^{-1}\right)$ were lower than those values in 150 - and 80 -day fetal muscle $\left(18 \pm 1.2\right.$ and $23 \pm 1.6 \mathrm{~S}$.E. nmoles $/ 10 \mathrm{~min} \bullet \mathrm{g}$ wet $\left.\mathrm{wt}^{-1}\right)$. This difference in enzyme activity relative to growth was also apparent in the $100,000 \times g$ particulate fractions of adult muscle $\left(2.5 \pm 0.2 \mathrm{~S}\right.$.E. $\mathrm{nmol} / 10 \mathrm{~min} \bullet \mathrm{g}$ wet $\left.\mathrm{wt}^{-1}\right)$ compared to the 150 and 80-day fetal muscle $(12 \pm 1.5$ and $14 \pm 1.9$ S.E. nmoles/10 $\min \bullet \mathrm{g}$ wet $\mathrm{wt}^{-1}$ ). The fluoride-stimulated adenylate cyclase activities of the homogenates and particulates and the increases in enzyme activity with fluoride were also at least four-fold greater in 80- and 150-day fetal than in adult muscle. When basal adenylate cyclase activities of homogenates were compared on the basis of the nitrogen content of the fraction analyzed rather than on the wet weight of the original samples, the differences in enzyme activities of the adult compared to the fetal series were even greater because of the lower nitrogen content of fetal muscle (1.8 $\pm 0.2 \mathrm{~S}$.E. nmoles $/ 10 \mathrm{~min} \cdot 10 \mathrm{mg} \mathrm{N}^{-1}$ for the adult series and 10.2 \pm 0.7 and $22.2 \pm 1.2 \mathrm{~S}$.E. nmoles $/ 10 \mathrm{~min} \cdot 10 \mathrm{mg} \mathrm{N}^{-1}$ for the 150 and 80-day series). The difference in activity with age was again apparent in the $100,000 \times g$ particulate fractions $(1.9 \pm 0.2 \mathrm{~S}$.E. nmoles $/ 10 \mathrm{~min} \cdot \mathrm{g}$ wet $\mathrm{wt}^{-1}$ for the adult series and $9.8 \pm 0.9 \mathrm{~S}$.E. and $24 \pm 2.2 \mathrm{nmoles} / 10 \mathrm{~min} \cdot \mathrm{g}$ wet $\mathrm{wt}^{-1}$ for the 150 - and 80 -day series). Because the nitrogen content of the 80 -day fetal muscle was less than that of the 150-day series, the adenylate cyclase activities per $\mathrm{mg} \mathrm{N}$ were highest in the younger fetal series. In the presence of guanylylimidodiphosphate the percent increase in adenylate cyclase activity was two to three times greater in the fetal particulate preparations than in the adult and was concentration-dependent in both series.
\end{abstract}

The basal guanylate cyclase activities for both the $100,000 \times g$ supernatant and particulate fractions were higher in 80-day fetal than in adult muscle; two- to three-fold higher in terms of wet wt and over six-fold higher in terms of nitrogen. Both the absolute and percentage increases in activity of the fetal particulate enzyme with Triton were at least twice those of the adult. Triton had no effect on the enzyme activity of the $100,000 \times g$ supernatant fraction of either series. The concentration of cyclic adenosine 3': $5^{\prime}$-monophosphate was 8 to 10 times higher in rapidly growing than in adult muscle, and the concentration of cyclic guanosine $5^{\prime}$ monophosphate was 26 to 62 times greater.

\section{Speculation}

There is a striking difference in the degree of maturation at birth of skeletal muscle in different species of animals. Skeletalmuscle from the rhesus fetus is particularly suitable for study if one is interested in human fetal muscle metabolism because the maturation rate of this tissue (on the basis of percent of gestation) is similar in the two species. Because fetal tissues must proliferate and differentiate, they must perform synthetic processes at a rapid rate, and synthetic processes are expensive in terms of energy. Therefore, it is not surprising that a number of fetal enzymes are more active than are those of the adult. In addition, a greater sensitivity of fetal enzymes to effector molecules may further magnify the activity of these enzymes. It would be of interest to measure the cyclic nucleotide-dependent protein kinase activities in fetal and adult rhesus muscle. Recent evidence suggests possible differences in the functions of types I and II cAMP-dependent protein kinases in relation to cellular growth and differentiation. Studies of these kinases in rhesus fetal muscle during the predominantly proliferative phase (earlier than 85 days gestation) and during the period when differentiation is predominant ( 85 to 110 days) should be of value in studying the biologic significance of these kinases.

The ontogeny of the enzymes that synthesize and degrade cAMP and cGMP in mammalian tissues has recently received considerable attention. Evidence obtained in the past few years indicates that cyclic nucleotides play an important role in the growth, differentiation, and/or specialization of cells $(14,15,17)$. Studies with tissue cultures originally led to the hypothesis that the cellular level of cyclic adenosine $3^{\prime}: 5^{\prime}$-monophosphate (cAMP) was inversely related to cell proliferation (31). In myoblasts, Zalin and Montague (43) have suggested a causal relationship between the increases in adenylate cyclase activity, the peak in intracellular cAMP leyels, and the onset of cell fusion; Moriyama et al. (26) have data that suggest a role for both cAMP and cGMP in the regulation of myoblast differentiation in culture. Indeed, recent evidence suggests the involvement of both cAMP and cyclic guanosine $3^{\prime}: 5^{\prime}$-monophosphate (cGMP) in the regulation of proliferation because each nucleotide is linked to different phases of the cell cycle (16). Whether these phenomena are relevant to muscle cells in vivo remains to be established (21). However, changes in cAMP levels and adenylate cyclase activities associated with development in vivo have been reported for several tissues, including skeletal muscle and heart $(18,25,29,40)$. cAMP levels are usually lower in perinatal skeletal muscle of rats than in adult muscle. Takahashi et al. (37) reported a sharp rise in the cAMP level of rat muscle shortly after birth and a subsequent decrease. The cGMP was highest in neonatal muscle and fell progressively until it reached adult levels. The low level of cAMP in fetal rat muscle suggests a minimal response of adenylate cyclase to stimulation, and there is evidence that the expression of adenylate cyclase hormone sensitivity occurs at a later stage of development than does the expression of catalytic activity $(32,33,35)$.

In the experiments reported here, we compared the basal adenylate cyclase activities of homogenates and $100,000 \times g$ supernatant and particulate fractions of rhesus skeletal muscle from adults and 150- and 80-day fetuses. The sensitivity of these preparations to fluoride, GTP, and GMP-P(NH)P (guanylylimidodiphosphate) 
early in fetal life (day 80 ) was also investigated. The basal and Triton-stimulated activities of guanylate cyclase of fetal and adult rhesus muscle were also studied in homogenates and subcellular fractions. Previous work in our laboratory had shown that cAMPphosphodiesterase (cAMP-PDE) and cGMP-phosphodiesterase (cGMP-PDE) activities were higher in fetal than in adult rhesus skeletal muscle (5).

\section{MATERIALS AND METHODS}

Rhesus fetuses (Macaca mulatta) at 80- to 150-days gestational age and adult rhesus monkeys were used. The average gestational period in out colony is 165 days. The mothers were anesthetized with dl-2-(o-chlorophenyl)-2-(methylamino)cyclohexanone hydrochloride (Ketaject; $10 \mathrm{mg} / \mathrm{kg}$ ) intramuscularly; the fetuses were given $1 \mathrm{mg}$ of Ketaject via the umbilical vein. Fetal muscle (arm) samples for determination of cyclic nucleotide levels were obtained in surgery before the cord was cut and were immediately frozen ( 5 to $10 \mathrm{sec}$ ) with a Wollenberger clamp at liquid nitrogen temperature. The fetus was then delivered, and samples of the skeletal muscle (legs) plus the heart and diaphragm were cut into small pieces and freeze-clamped ( 5 to $10 \mathrm{~min}$ ). Samples of adult sartorius muscle were freeze-clamped in situ, or the entire muscle was dissected free, and small samples were freeze-clamped within 5 to $10 \mathrm{~min}$ of excision. These 5- to 10 -min biopsies were used for enzyme assays because there was no difference in the enzyme activity in situ and at $10 \mathrm{~min}$, or in fresh compared to frozen muscle.

\section{PREPARATION OF CELLULAR FRACTIONS}

The frozen samples were weighed and ground in a mortar and pestle cooled to liquid nitrogen temperature. The pulverized tissue ( 8 to $10 \% \mathrm{w} / \mathrm{v}$ ) was homogenized in $0.25 \mathrm{M}$ sucrose- $10 \mathrm{mM}$ tris(hydroxymethyl)aminomethane (Tris) at $4^{\circ} \mathrm{C}$ in a Polytron ST20 for $10 \mathrm{sec}$ at three-fourths the maximum setting. For the adenylate cyclase assay, the whole homogenate was spun at $100,000 \times g$ for $10 \mathrm{~min}$, the pellet was washed with homogenizing medium and respun, and the supernatants were combined. All centrifugations were done at $4^{\circ} \mathrm{C}$. The whole homogenate was analyzed, as were the cellular fractions; there was no adenylate cyclase activity in the $100,000 \times g$ supernatant. For analysis of guanylate cyclase activity, the whole homogenate and the subcellular fractions were prepared as previously described (5), and the percent of total activity present in each fraction was determined $(10,000 \times g$ particulate and $100,000 \times g$ particulate and superna$\tan t)$. Otherwise, the whole homogenate was spun at $100,000 \times g$, and the supernatant and pellet were analyzed. The fractions were analyzed immediately or were quick-frozen in liquid nitrogen and stored at $-200^{\circ} \mathrm{C}$ for future analysis. The adenylate cyclase fractions maintained their activity for 2 days at $-200^{\circ} \mathrm{C}$; the guanylate cyclase was maintained for at least 6 months. No attempt was made to further purify the fractions before assay because this procedure usually results in large variable losses in the total activity recovered concomitant with the increase in specific activity per $\mathrm{mg}$ protein in the fraction analyzed.

\section{ADENYLATE AND GUANYLATE CYCLASE}

We determined the adenylate cyclase activity (4) by a modification of the method of Wincek and Sweat (41) that measures the formation of $\left[{ }^{32} \mathrm{P}\right]$ cAMP from $\left[\alpha-{ }^{32} \mathrm{P}\right] \mathrm{ATP}$. The guanylate cyclase activity in tissue extracts was determined by a modification of the method of Nesbitt et al. $(4,28)$, except that the substrate level of GTP was $0.5 \mathrm{mM}$. Linearity of the reactions with time and protein concentration was established. The loss of product due to cAMPPDE activity was less than $2 \%$ and that due to cGMP-PDE less than $1 \%$; both losses were ignored.

\section{CYCLIC NUCLEOTIDE LEVELS}

Cyclic nucleotide concentrations were determined on the supernatant from frozen tissues homogenized in $6 \%$ trichloroacetic acid.
After centrifugation, trichloroacetic acid supernatant was passed through an alumina oxide and a Dowex column (200 to 400 mesh $\mathrm{Cl}^{-}$form) (23), and the cAMP and cGMP concentrations were determined by radioimmunoassay (New England Nuclear kits).

\section{TOTAL NITROGEN}

The nitrogen contents of the tissues and subcellular fractions were determined on a Kjeldahl digest with a Technicon autoanalyzer.

\section{STATISTICAL ANALYSIS}

Estimates of significant differences between groups were made with the $t$ test for comparison of two independent means. Differences in means were not considered significant unless the $P$ values were $<0.05$ (1). $\mathrm{K}_{\mathrm{m}}$ and $\mathrm{V}_{\max }$ values were determined by the method of linear regression (least squares). With this calculation, our program also gave us a value for correlation coefficients so we were able to estimate the accuracy of our data. Because all our $\mathrm{K}_{\mathrm{m}}$ and $\mathrm{V}_{\max }$ calculations had a correlation coefficient of greater than 0.896 , our data can be considered very reliable $(P<0.01 ; n=10)$.

\section{RESULTS}

\section{ADENYLATE CYCLASE ACTIVITY}

The basal and fluoride-stimulated $(8 \mathrm{mM})$ adenylate cyclase activities (per gram wet wt or per gram nitrogen) of fetal skeletal muscle homogenates as well as the increase in activity with fluoride were at least four-fold greater in both 80- and 150-day fetal muscle than in adult muscle (Table 1). The higher values for adenylate cyclase activity in fetal muscle agree with data from previous work in our laboratory which showed that the increase in $\left[{ }^{14} \mathrm{C}\right] \mathrm{cAMP}$ production from labeled ATP in the presence of epinephrine is greater with fetal than with adult muscle fiber groups (in vitro) (6). When the homogenate was separated into $100,000 \times g$ supernatant and particulate fractions, no significant adenylate cyclase activity remained in the supernatant fraction; the activity in the particulate fraction was 60 to $85 \%$ of that in the whole homogenate. However, the adenylate cyclase activities of the particulate, both basal and fluoride-stimulated, as well as the absolute increases in enzyme activity with fluoride, were more than four-fold higher in fetal than in adult preparations. The activities of the recombined $100,000 \times g$ supernatant and particulate fractions for the adult and the 150-day series were higher than those of the original homogenate (Table 1). These differences could not be explained by differences in total volumes or in protein contents of the reconstituted homogenates. In the 80-day fetal series (fluoride present), the reconstituted homogenate was less active than the original homogenate, and the addition of an adult or 150-day fetal supernatant fraction (fluoride present) did not stimulate this 80-day fetal particulate (data not shown).

When the adenylate cyclase activities were compared on the basis of the nitrogen content of the fraction analyzed rather than on the basis of the wet weight of the original samples, the differences in fetal compared to adult activity were greater because of the lower nitrogen content of fetal muscle (Table 1). Furthermore, since the nitrogen content of the 80-day fetal muscle was less than that of the 150-day series, the enzyme activities were higher in the younger fetal series (Table 1) (3). In the presence of fluoride, the percent increase in the particulate enzyme activity when the supernatant or $100 \mu \mathrm{M}$ GTP was added was similar in the adult and fetal series (Fig. 1). However, with GMP-P(NH)P, the percent increase was greater in the fetal preparation and was concentration-dependent in both series. In agreement with these results, Nambi and Drummond (27) have reported that GMP$\mathrm{P}(\mathrm{NH}) \mathrm{P}$ activation of adenylate cyclase of rabbit muscle membranes was concentration-dependent. Because the basal (no fluoride) enzyme activity was more than 10 -fold higher (in terms of nitrogen) in the 80-day fetal than in the adult series (Table 1), the absolute increases in enzyme activity with the addition of GTP or 
Table 1. Adenylate cyclase activity in skeletal muscle of fetal and adult rhesus monkeys

\begin{tabular}{|c|c|c|c|c|c|c|c|}
\hline & \multicolumn{3}{|c|}{ Homogenate } & \multirow[b]{2}{*}{ Basal } & \multicolumn{2}{|c|}{$100,000 \times g$ pellet } & \multirow{2}{*}{$\begin{array}{c}\text { Pellet plus } \\
\text { supernatant } \\
\text { (fluoride) }\end{array}$} \\
\hline & Basal & Fluoride & $\begin{array}{l}\text { Increase plus flu- } \\
\text { oride }\end{array}$ & & Fluoride & $\begin{array}{l}\text { Increase plus flu- } \\
\text { oride }\end{array}$ & \\
\hline \multicolumn{8}{|c|}{ Activity (nmoles $/ 10 \mathrm{~min} \cdot \mathrm{g}$ wet $\mathrm{wt}^{-1}$ ) } \\
\hline Adult & $4 \pm 0.4^{1}$ & $32 \pm 1.1$ & $28 \pm 2.1$ & $\begin{array}{c}2.5 \pm 0.2^{2} \\
(62 \%)^{3}\end{array}$ & $\begin{array}{c}24 \pm 2.6^{2} \\
(75 \%)\end{array}$ & $22 \pm 1.9$ & $\begin{array}{l}40 \pm 4.0 \\
(122 \%)\end{array}$ \\
\hline \multicolumn{8}{|l|}{ Fetal } \\
\hline 150-day & $18 \pm 1.2$ & $122 \pm 6.5$ & $103 \pm 5.9$ & $\begin{array}{c}12 \pm 1.5^{2} \\
(65 \%)\end{array}$ & $\begin{array}{c}104 \pm 8.0^{4} \\
(85 \%)\end{array}$ & $92 \pm 9.0$ & $\begin{array}{c}180 \pm 13^{2} \\
(147 \%)\end{array}$ \\
\hline 80-day & $23 \pm 1.6$ & $144 \pm 5.5$ & $121 \pm 10$ & $\begin{array}{c}14 \pm 1.9^{2} \\
(61 \%)\end{array}$ & $\begin{array}{l}121 \pm 10^{4} \\
(84 \%)\end{array}$ & $107 \pm 8.9$ & $\begin{array}{c}123 \pm 11^{5} \\
(86 \%)\end{array}$ \\
\hline \multicolumn{8}{|c|}{ Activity (nmoles/10 $\mathrm{min} \cdot 10 \mathrm{mg} \mathrm{N}^{-1}$ ) } \\
\hline $\begin{array}{l}\text { Adult } \\
\text { Fetal }\end{array}$ & $1.8 \pm 0.2$ & $14.4 \pm 0.6$ & $12.6 \pm 1.2$ & $1.9 \pm 0.2$ & $17.4 \pm 1.8^{5}$ & $15.5 \pm 2.0$ & $16.9 \pm 1.6^{5}$ \\
\hline 150-day & $10.2 \pm 0.7$ & $70.0 \pm 3.5$ & $59.8 \pm 3.5$ & $9.8 \pm 0.9$ & $88 \pm 7.1^{5}$ & $78.2 \pm 8.0$ & $94.1 \pm 5.5^{5}$ \\
\hline 80-day & $22.2 \pm 1.2$ & $142 \pm 7.0$ & $120 \pm 11.0$ & $24 \pm 2.2$ & $210 \pm 12^{5}$ & $186 \pm 16$ & $152 \pm 6.5$ \\
\hline
\end{tabular}

${ }^{\prime}$ Mean \pm S.E.; six monkeys in the adult and 150-day fetal series, seven monkeys in the 80 -day fetal series (duplicate or triplicate analyses). There is less than $1 \%$ of the basal or fluoride-stimulated adenylate cyclase activity in the $100,000 \times g$ supernatant. $P$ values for fetal versus adult enzyme activity $<0.005$ in every series. Substrate level, $0.5 \mathrm{mM} \mathrm{ATP}$.

${ }^{2} P$ value compared to homogenate $<0.01$ (paired analyses).

${ }^{3}$ Numbers in parentheses, activity in the pellet $\div$ the activity in the homogenate $\times 100$.

${ }^{4} P$ value compared to homogenate $<0.02$ (paired analyses).

${ }^{5} P$ value compared to homogenate $<0.05$ (paired analyses).

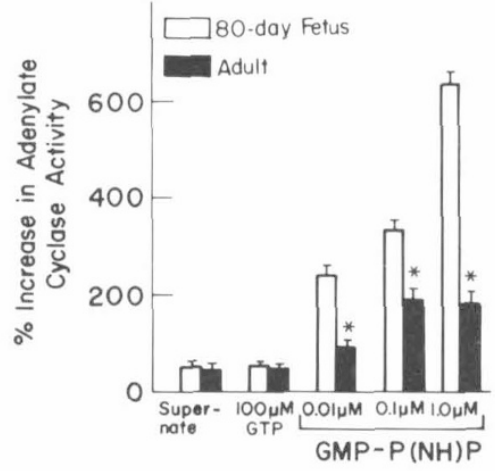

Fig. 1. Effect of supernatant, GTP, and GMP-P(NH)P on the adenylate cyclase activity of the $100,000 \times g$ particulate of skeletal muscle from three 80 -day fetal and four adult rhesus monkeys (duplicate or triplicate determinations; vertical lines represent I S.E.). The additions stimulated activity in all 10 series $(P<0.02){ }^{*}, P$ values for the difference between fetal and adult sensitivity to GMP-P(NH)P $<0.02$.

supernatant were also greater in the fetal than in the adult particulate fractions

As one would expect, the apparent $V_{\max }$ values (with or without fluoride) for adenylate cyclase activity (homogenate and particulate) were greater in the fetal than in the adult series; fluoride increased the $\mathrm{V}_{\max }$ values in all the series (Table 2). The addition of $8 \mathrm{mM}$ fluoride to the homogenate did not change the apparent $K_{m}$ values, but decreased the particulate $K_{m}$ values in all three series. The $\mathrm{K}_{\mathrm{m}}$ values for the fetal series, with or without fluoride, were usually lower than those for the adult. Reddy et al. (34) reported $\mathrm{K}_{\mathrm{m}}$ values of 0.3 to $0.35 \mathrm{mM}$ for ATP from human skeletal muscle (plasmalemma), and Severson et al. (36) found similar $K_{m}$ values for rabbit sarcolemmal activity.

\section{GUANYLATE CYCLASE ACTIVITY}

When the percent distribution of guanylate cyclase activity (nmoles cGMP produced per $15 \mathrm{~min} \cdot \mathrm{g}$ wet $\mathrm{wt}^{-1}$ ) was calculated on the basis of the activity in the whole homogenate, there was no difference between the fetal and adult series. There was 8 to $10 \%$ of the total activity in the $10,000 \times g$ pellet (with and without
Triton treatment); about $65 \%$ in the $100,000 \times g$ supernatant without and $50 \%$ with Triton; and $19 \%$ in the $100,000 \times g$ pellet without and $30 \%$ with Triton. The guanylate cyclase activities of both the basal and Triton-treated $100,000 \times \mathrm{g}$ supernatant and particulate fractions were higher in 80-day fetal than in adult muscle (Table 3).

When the activities were compared on the basis of nitrogen rather than wet weight, as with the adenylate cyclase activities, the differences in fetal compared to adult activities were increased owing to the lower nitrogen concentration in the fetal series (Table 3 ). Both the absolute and percentage increases in activity of the fetal particulate enzyme with Triton were at least twice those of the adult when the values were compared on the basis of wet wt or nitrogen. Triton had no affect on the enzyme activity of the $100,000 \times g$ supernatant fraction of either series. In two experiments at 150-days gestation, the basal values for the supernatant and particulate guanylate cyclases were about one-half those at 80 days $\left(2.2=0.3\right.$ and $0.89 \pm 0.10 \mathrm{nmoles} / 15 \mathrm{~min} \cdot \mathrm{mg} \mathrm{N}^{-1}$, respectively).

\section{CYCLIC NUCLEOTIDE CONCENTRATIONS IN MUSCLE}

The greater activities of both adenylate and guanylate cyclases in rapidly growing muscle were reflected in higher levels of both cyclic nucleotides in fetal than in adult muscle (Table 4). The lower cAMP/cGMP ratios observed in fetal compared to adult muscle were due to the high concentrations of cGMP, which decreased progressively with fetal age. The cAMP level also decreased with fetal age; however, this decrease was less striking. The cAMP/cGMP ratio in adult rat muscle was also high, i.e., 29 compared to the value of 40 in rhesus muscle (9). Concomitant with the drop in cyclic nucleotides and the increase in the cAMP/ cGMP ratio, a steady decrease in the DNA concentration was seen from 80 to 110 days gestation from $200 \pm 10$ to $120 \pm 9 \mathrm{mg} /$ g N (Beatty et al., unpublished data).

\section{DISCUSSION}

There has been considerable interest recently in the ontogeny of enzymes and their sensitivity to effector molecules in mammalian tissues. For example, in rat brain there is a difference in the time of development of basal enzyme activity and responsiveness 
Table 2. Kinetic values for adenylate cyclase and guanylate cyclase enzymes of skeletal muscle from fetal and adult rhesus monkeys

\begin{tabular}{|c|c|c|c|c|c|c|c|c|}
\hline & \multicolumn{8}{|c|}{ Adenylate cyclase } \\
\hline & \multicolumn{4}{|c|}{ Homogenate } & \multicolumn{4}{|c|}{$100,000 \times g$ pellet } \\
\hline & \multicolumn{2}{|c|}{$\mathrm{K}_{\mathrm{m}}{ }^{1}(\mu \mathrm{M})^{2}$} & \multicolumn{2}{|c|}{$\mathrm{V}_{\max }{ }^{3}$} & \multicolumn{2}{|c|}{$\mathrm{K}_{\mathrm{m}}(\mu \mathrm{M})^{2}$} & \multicolumn{2}{|c|}{$\mathrm{V}_{\max }{ }^{3}$} \\
\hline & Basal & Fluoride & Basal & Fluoride & Basal & Fluoride & Basal & Fluoride \\
\hline Adult $(2)^{4}$ & 513 & 500 & 0.39 & 3.6 & 502 & 89 & 0.72 & 1.7 \\
\hline \multirow{7}{*}{$\begin{array}{l}\text { Fetal } \\
\qquad \begin{array}{l}\text { 140-day (1) } \\
80 \text {-day (2) }\end{array}\end{array}$} & & & & & & & & \\
\hline & 183 & 218 & 1.22 & 9.7 & 250 & 100 & 2.19 & 9.4 \\
\hline & 208 & 240 & 3.05 & 22.0 & 303 & 120 & 3.80 & 21.0 \\
\hline & \multicolumn{8}{|c|}{ Guanylate cyclase } \\
\hline & \multicolumn{4}{|c|}{$100,000 \times g$ supernatant } & \multicolumn{4}{|c|}{$100,000 \times g$ pellet } \\
\hline & \multicolumn{2}{|c|}{$\mathrm{K}_{\mathrm{m}}(\mu \mathrm{M})^{5}$} & \multicolumn{2}{|c|}{$V_{\max }{ }^{6}$} & \multicolumn{2}{|c|}{$\mathrm{K}_{\mathrm{m}}(\mu \mathrm{M})^{5}$} & \multicolumn{2}{|c|}{$\mathrm{V}_{\max }{ }^{6}$} \\
\hline & Basal & Triton $^{7}$ & Basal & Triton & Basal & Triton $^{7}$ & Basal & Triton ${ }^{7}$ \\
\hline Adult & 281 & & 0.83 & & 315 & 333 & 0.49 & 1.82 \\
\hline Fetal (80-day) & 441 & & 5.0 & & 555 & 542 & 3.7 & 19.8 \\
\hline
\end{tabular}

${ }^{1}$ The apparent $\mathrm{K}_{\mathrm{m}}$ and $\mathrm{V}_{\max }$ values were determined by the method of least squares. Duplicate determinations were done for at least five substrate levels of ATP $(0.075$ to $3 \mathrm{mM})$ and GTP $(0.1$ to $0.5 \mathrm{mM})$.

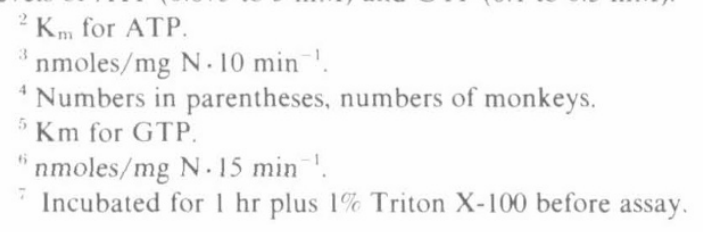

Table 3. Guanylate cyclase activity in skeletal muscle of fetal and adult rhesus monkeys

\begin{tabular}{|c|c|c|c|c|c|c|c|}
\hline & \multirow[b]{2}{*}{$N^{1}$} & \multicolumn{3}{|c|}{$100,000 \times g$ supernatant } & \multicolumn{3}{|c|}{$100,000 \times g$ pellet } \\
\hline & & Basal & Triton $^{2}$ & $P^{3}$ & Basal & Triton $^{2}$ & $P^{3}$ \\
\hline \multicolumn{8}{|c|}{ Activity (nmoles $/ 15 \mathrm{~min} \cdot \mathrm{g}$ wet $\mathrm{wt}^{-1}$ ) } \\
\hline Adult & 5 & $3.69 \pm 0.51^{4}$ & $4.16 \pm 0.50$ & NS & $3.56 \pm 0.43$ & $11.3 \pm 0.55$ & $<0.005$ \\
\hline Fetal (80-day) & 5 & $11.6 \pm 1.9$ & $14.2 \pm 0.9$ & NS & $6.75 \pm 0.72$ & $47.6 \pm 1.3$ & $<0.005$ \\
\hline \multicolumn{8}{|c|}{ Activity (nmoles/15 $\mathrm{min} \cdot \mathrm{mg} \mathrm{N}^{-1}$ ) } \\
\hline Adult & 5 & $0.61 \pm 0.12$ & $0.60 \pm 0.05$ & NS & $0.26 \pm 0.03$ & $0.91 \pm 0.05$ & $<0.005$ \\
\hline Fetal (80-day) & 5 & $4.00 \pm 0.37$ & $4.42 \pm 0.18$ & NS & $1.62 \pm 0.03$ & $10.1 \pm 0.2$ & $<0.005$ \\
\hline
\end{tabular}

${ }^{\prime} N$, number of monkeys.

${ }^{2}$ Incubated for 1 hr plus $1 \%$ Triton X-100 before assay

${ }^{3} P$ value for addition of Triton.

${ }^{4}$ Mean \pm S.E. (duplicate or triplicate analysis). $P$ values for fetal versus adult series $<0.005$ in all instances.

Table 4. Levels of cyclic nucleotides in skeletal muscle of fetal and adult rhesus monkeys'

\begin{tabular}{lccc}
\hline \multicolumn{2}{c}{ pmoles $/ \mathrm{mg} \mathrm{N}$} & \\
\cline { 2 - 3 } & \multicolumn{2}{c}{ cAMP } & Ratio \\
\hline Fetus & & & \\
80 -day (9) & & \\
89-day (5) & $50.0 \pm 4.0^{3}$ & $7.4 \pm 0.4$ & 6.8 \\
110-day (5) & $44.0 \pm 3.0$ & $4.4 \pm 0.8$ & 10 \\
& $39.0 \pm 6.0$ & $3.1 \pm 0.3$ & 13 \\
Adult (5) & $4.8 \pm 0.4$ & $0.12 \pm 0.01$ & 40 \\
\hline
\end{tabular}

\footnotetext{
' The $P$ value for the fetal versus the adult series was always $<0.005$.

${ }^{2}$ Numbers in parentheses, number of animals.

${ }^{3}$ Averages \pm S.E. of duplicate determinations.
}

to effector molecules and catecholamines (32). Basal activity is present on the day of birth; however, sensitivity to adenosine and norepinephrine could not be demonstrated until day 10 . In rat heart, the epinephrine-guanyl nucleotide-adenylyl cyclase system appears to be "mature" as a functional unit just before birth (9). Severson et al. (36) have reported that catecholamines stimulate the plasmalemmal adenylate cyclase enzyme of adult skeletal muscle in a typical $\beta$-adrenergic fashion. It is generally accepted that activation of $\beta$-receptors usually results in an increase in the cAMP level via activation of adenylate cyclase (22). In rat skeletal muscle, Reddy et al. (33) have reported that although $\beta$-adrenergic receptors are present before birth, functional coupling of $\beta$-receptors and adenylate cyclase does not occur until after birth, when catecholamines first increase adenylate cyclase activity. However, our laboratory has previously reported that with rhesus skeletal muscle fiber groups the increase in cAMP production in vitro in the presence of epinephrine was twice as great in the 100-day fetal compared to the adult series (6).

The basal adenylate cyclase activity of rapidly growing cardiac and skeletal muscle in perinatal rodents is usually less than that in adults, and this enzyme has been variably reported as both insensitive and sensitive to GMP-P(NH)P, fluoride, and catecholamines $(8,39,42)$. However, if one is primarily interested in the study of human fetal metabolism, rat skeletal muscle is a particularly unsuitable tissue to use. Rat muscle is very immature at birth, and embryonal features do not disappear in rat muscle until the 10th to 14 th postnatal day $(12,13,20)$. Muscle fibers in the myotube stage predominate in the muscle of neonatal rats (over 90\%), and no differentiation into red and white fiber types can be demon- 
strated by histochemical techniques. Muscles from human beings and rhesus monkeys are well differentiated at birth into red and white fiber types (7). Histochemically, skeletal muscle of the fetal rat at $90 \%$ of gestation resembles rhesus fetal muscle at about $30 \%$ of gestation. In both rhesus monkeys and man, differentiation has occurred by $70 \%$ to $75 \%$ of gestation and the pattern of fiber types, determined by histochemical methods, is similar to that of adult muscle $(2,12,13,20)$. It appears that differences in muscle metabolism between fetal primates and fetal rats may be explained on the basis of their stage of development. At present, we have no metabolic data on rhesus skeletal muscle at 55 days fetal age to compare with the data on the perinatal rat muscle.

The problems of studying fetal metabolism in human tissues are readily apparent. Hence, the advantage of using nonhuman primates, whose physiology and biochemistry are more closely related to those of man than those of rats, becomes obvious to those who are primarily interested in the study of human metabolism. A few workers $(10,11,24,30)$ have measured cardiac adenylate cyclase activity of human fetuses at term or before and have found that the enzyme is sensitive to fluoride and catecholamines before birth. More work appears to have been done on cardiac than on skeletal muscle, although Menon et al. (24) have reported the presence of adenylate cyclase in skeletal muscle of three fetuses early in pregnancy. However, the developmental pattern for these two tissues is significantly different because the heart is a constantly active organ and starts work earlier. Furthermore, in vitro comparisons of enzyme activities and sensitivities of muscle from fetal, neonatal, and adult humans are rare. It is difficult to obtain human biopsies postnatally; when enzyme activities are measured in human fetal muscles, neonatal and adult values are usually not available. However, because fetal rhesus muscle fibers show a pattern of differentiation similar to that of adult muscle at about the same time (percent of gestation) as do human muscle fibers, data on rhesus are reasonably applicable to man $(2,12,38)$.

In our experiments with rhesus monkeys, the basal (unstimulated) adenylate and guanylate cyclase enzyme activities were higher in fetal than in adult muscle as early as midterm. In addition, the fetal enzymes were frequently more sensitive to stimulation (GTP, GMP-P(NH)P, fluoride, and Triton) than were the adult enzymes. We previously reported that cAMP-PDE and cGMP-PDE enzymes were more active in fetal than in adult rhesus muscle (5). None of these experiments differentiated between changes in the following variables: the number or affinity of receptors; the number of enzyme molecules; the amount of modulator(s); and an alteration in enzyme kinetics.

Because the levels of cAMP and cGMP are higher in fetal muscle (5), it is not surprising that adenylate and guanylate cyclase activities are also greater in fetal compared to adult muscle. However, the in vitro activities may not exactly duplicate the in vivo activities because the tissue levels of effector molecules are important in the regulation of enzyme activity, and fetal enzymes are often very sensitive to effector molecules. For example, phosphodiesterase from fetal rhesus muscle is more sensitive than is the adult enzyme to stimulation with cGMP (5).

Takahashi et al. (37) found a high level of cAMP and a low level of cGMP in rat muscle concurrent with the period of cell differentiation. In fetal rhesus muscle, we found no dramatic changes in cyclic nucleotide levels during the period when cells differentiate into red and white fiber types, from 85 to 110 days gestation. Instead, we found a gradual decrease in both nucleotides concomitant with a gradual increase in the cAMP/cGMP ratio; at midterm, the levels of both cyclic nucleotides were at least 10 times higher in fetal than in adult muscle. It seems that, although the activities of the cyclases forming and the phosphodiesterases degrading cyclic nucleotides are both greater in rapidly growing fetal than in adult muscle, the balance between the two processes favors synthesis to a greater degree in the fetal tissues. The data on nonhuman primates are particularly sparse, and right now, we can only conclude that cyclic nucleotides appear to play some role in the regulation of growth and differentiation in primate muscle.
REFERENCES AND NOTES

1. Arkin, H, and Colton, R. R.: An outline of statistical methods, pp. 50-97 (Barnes and Noble. Inc.. New York. 1950).

2. Beatty. C. H.. Basinger, G. M., and Bocek, R. M.: Differentiation of red and white fibers in muscle from fetal, neonatal and infant rhesus monkeys. J. Histochem. Cytochem., 15: 93 (1967).

3. Beatty, C, H.. and Bocek, R. M.: Metabolic aspects of fetal skeletal muscle. In: D. Cheek: Fetal and Postnatal Cellular Growth: Hormones and Nutrition. pp. 257-271 (John Wiley \& Sons, New York, 1975).

4. Beatty, C. H., Bocek. R. M., Herrington. P. T., Young. M. K., and Brenner, R. $M$.: Effects of estradiol- $17 \beta$ and progesterone on cyclic nucleotide metabolism in myometrium of macaques. Biol. Reprod., 21: 309 (1979).

. Beatty, C. H., Herrington. P. T.. and Bocek, R. M.: Regulation of cyclic nucleotide phosphodiesterase activity in rhesus fetal muscle. Biol. Neonate. 32: 33 (1977).

6. Bocek, R.M., Young, M. K., and Beatty, C. H.: Effect of insulin and epinephrine on the carbohydrate metabolism and adenylate cyclase activity of rhesus fetal muscle. Pediatr. Res., 7: 787 (1973).

. Bocek, R. M., Young, M. K., and Beatty. C. H.: Cyclic AMP in developing muscle of the rhesus monkey. Biol. Neonate, 28: 92 (1976).

8. Brus. R.. and Hess, M. E.: Effect of norepinephrine and sodium fluoride on heart adenyl cyclase in newborn and adult rats. Endocrinology, 93: 982 (1973).

9. Clark. J. B., Vinicor. F., Carr. L.. and Clark. Jr.. C. M.: Adenylyl cyclase responsiveness to guanyl nucleotides in the developing rat heart. Pediatr. Res. 14: $291(1980)$

10. Coltart. D. J., Davies, G. M., Gillibrand, I. M., and Hames, J.: Adenyl cyclase activity in the developing human foetal heart. J. Physiol. (Lond.), 225:38P (1972).

11. Constantopoulos, A., Xypolita, A., and Matsaniotis, N.: Adenylate cyclase activity in human tissues. Biol. Neonate, 29: 294 (1976).

12. Dubowitz. V.: Enzyme histochemistry of skeletal muscle. J. Neurol. Neurosurg Psychiatr. 28: 516 (1965).

13. Engel, W. K., and Karpati, G.: Impaired skeletal muscle maturation following neonatal neurectomy. Dev. Biol.. 17: 713 (1968)

14. Friedman, D. L.: Role of cyclic nucleotides in cell growth and differentiation. Physiol. Rev.. 56: 652 (1976).

15. Friedman, D. L., Johnson. R. A., and Zeilig. C. E.: The role of cyclic nucleotides in the cell cycle. Adv. Cyclic Nucleotide Res.. 7: 69 (1976).

16. George, W. J.. Rodgers, G. M... and White. L-A.: Cyclic nucleotides as regulators of erythrocyte proliferation. Adv. Cyclic Nucleotide Res.. 9: 517 (1978).

17. Goldberg, N. D., and Haddox. M. K.: Cyclic GMP metabolism and involvement in biological regulation. Ann. Rev. Biochem.. 46: 823 (1977).

18. Hommes, F. A.. and Beere. A.: The development of adenyl cyclase in rat liver. kidney, brain, and skeletal muscle. Biochim. Biophys. Acta, 237: 296 (1971).

19. Ishikawa, E. Ishikawa, S., Davis, J. W.. and Sutherland, E. W.: Determination of guanosine 3'. 5'-monophosphate in tissues and of guanylate cyclase in rat intestine. J. Biol. Chem., 244: 6371 (1969).

20. Kamieniecka, Z., and Ostenda, M.: Histochemical investigations in maturation of rat skeletal muscle after whole-body gamma-irradiation at the fourth day of life. J. Neurol. Sci., 9: 347 (1969).

21. Kloosterboer. H. J., Van Faasen. H.. Stoker-deVries, S. A., and Hommes. F. A Effect of cyclic nucleotides on the weight of gastrocnemius and creatine kinase activity after denervation of muscle in young rats. Biol. Neonate, 36: 160 (1979).

22. Malbon, C. C.: Avenues of adrenergic research. J. Lab. Clin. Med., 94: 381 (1979)

23. Mao, C. C. and Guidotti. A.: Simultaneous isolation of adenosine $3^{\prime}, 5^{\prime}$-cyclic monophosphate (cAMP) and guanosine $3^{\prime} .5^{\prime}$-cyclic monophosphate (cGMP) in small tissue samples. Anal. Biochem., 59: 63 (1974).

24. Menon. K. M. J., Giese, S., and Jaffee, R. B.: Hormone- and fluoride-sensitive adenylate cyclases in human fetal tissues. Biochim. Biophys. Acta, 304: 203 (1973).

25. Mersmann, H. J.. Phinney, G., Brown, L. J.. and Steffen, D. G.: Ontogeny of adenylate cyclase and phosphodiesterase activities in swine tissues. Biol. Neonate, 32: 266 (1977)

26. Moriyama, Y.. Hasegawa, S., and Murayama, K.: cAMP and cGMP changes associated with the differentiation of cultured chick embryo muscle cells. Exp. Cell Res., 101: 159 (1976).

27. Nambi, P., and Drummond. G. I.: Catecholamine and guanine nucleotide activation of skeletal muscle adenylate cyclase. Biochim. Biophys. Acta, 583: 287 (1979).

28. Nesbitt, J. A., III, Anderson, W. B., Miller. Z., and Pastan, I.: Guanylate cyclase and cyclic guanosine $3^{\prime}: 5^{\prime}$-monophosphate phosphodiesterase activities and cyclic guanosine $3^{\prime}: 5^{\prime}$-monophosphate levels in normal and transformed fibroblasts. J. Biol. Chem., 251: 2344 (1976).

29. Novák. E., Drummond, G. I., Skála, J., and Hahn, P.: Developmental changes in cyclic AMP, protein kinase, phosphorylase kinase, and phosphorylase in liver, heart and skeletal muscle of the rat. Arch. Biochem. Biophys., 150: 511 (1972).

30. Palmer, G. C., and Dail, W. G.: Appearance of hormone-sensitive adenylate cyclase in the developing human heart. Pediatr. Res., 9: 98 (1975).

31. Pastan. I. H.. Johnson. G. S., and Anderson. W. B.: Role of cyclic nucleotides in growth control. Ann. Rev. Biochem., 44: 491 (1975).

32. Perkins, J. P.: Adenyl cyclase. Adv. Cyclic Nucleotide Res., 3: 2 (1973).

33. Reddy. N. B., Oliver. K. L., and Engel, W. K.: Developmental patterns of adenylate cyclase $(\mathrm{AC})$ and $\beta$-adrenergic receptor (BAR) in rat skeletal muscle. Fed. Proc., 38: 843 (1979). 
34. Reddy. N. B.. Oliver. K. L.. Festoff. B. W.. and Engel, W. K.: Adenylate cyclase system of human skeletal muscle, subcellular distribution and general properties. Biochim. Biophys. Acta. 540: 371 (1978).

35. Rosen. O. M.. and Rosen. S. M.: The effect of catecholamines on the adenyl cyclase of frog and tadpole hemolysates. Biochim. Biophys. Res. Commun. 31: 82 (1968).

36. Severson. D. L.. Drummond. G. I.. and Sulakhe. P. V.: Adenylate cyclase in skeletal muscle. Kinetic properties and hormonal stimulation. J. Biol. Chem. 247: 2949 (1972)

37. Takahashi. K.. Takai. T., and Takao, H.: Developmental changes of cyclic $3^{\prime}, 5^{\prime}$ guanosine and cyclic $3^{\prime} .5^{\prime}$-adenosine monophosphates in rat skeletal muscle. Exp. Neurol., 57: 928 (1977).

38. Van Wagenen. G., and Catchpole, H. R.: Physical growth of the rhesus monkey (Macaca mulatta). Am. J. Phys. Anthropol.. 14: 245 (1956).

39. Wildenthal. K.. Allen. D. O.. Karlsson. J.. Wakeland. J. R.. and Clark. C. M.. Jr. Responsiveness to glucagon in fetal hearts. J. Clin. Invest.. 57: 551 (1976)

40. Williams. R. H.. and Thompson. W. J.: Effect of age upon guanyl cyclase, adenyl cyclase and cyclic nucleotide phesphodiesterase. Proc. Soc. Exp. Biol. Med. 143: 382 (1973)

Copyright (c) 1981 International Pediatric Research Foundation. Inc. $0031-3998 / 81 / 1508-1105 \$ 02.00 / 0$
41. Wincek. T. J.. and Sweat. S. W.: The assay of adenyl cyclase by sequential Dowex-Alumina Chromatography. Anal. Biochem.. 64: 631 (1975).

42. Yount. E. A.. Clark. J. F., and Clark. C. M.. Jr.: Development of guanylimidodiphosphate-dependent activation of adenylate cyclase by glucagon in the neonatal heart. Pediatr. Res., 10: 85I (1976).

43. Zalin. R., and Montague W.: Changes in the level of $3^{\prime}, 5^{\prime}$-cyclic adenosine monophosphate and the activities of adenylate cyclase and protein kinase during differentiation of primary cultures of chick myoblasts. Adv. Cyclic Nucleotide Res.. 5: 832 (1975).

44. Requests for reprints should be addressed to: Dr. C. H. Beatty, Oregon Regional Primate Research Center, 505 N.W. 185th Avenue, Beaverton, OR 97006 (USA).

45. This research was supported in part by grant RR-00163 from NIH, Public Health Service Grants HD-06069 and HD-06425 from NICHHD, AG-01505 from NIA. and by General Research Support Grant RR-05694 from NIH. Publication 1114 of the Oregon Regional Primate Research Center.

46. Received for publication May 9, 1980

47. Accepted for publication November 21, 1980. 